\section{Cóndor, sistema para el autorrescate de andinistas}

Chile es un país de montañas, posee más territorio terrestre montañoso que de cualquier otro tipo. Las montañas son el escenario ideal para la práctica de deportes al aire libre; en los últimos años ha aumentado exponencialmente la cantidad de personas que practican montañismo.

El $52 \%$ de los montañistas chilenos dice haber tenido accidentes en la montaña; según el estudio realizado las lesiones producto de accidentes más comunes imposibilitan al accidentado poder salir del lugar por sus propios medios, requiriendo ayuda de otros.

En Chile no existe ninguna institución especializada en el rescate

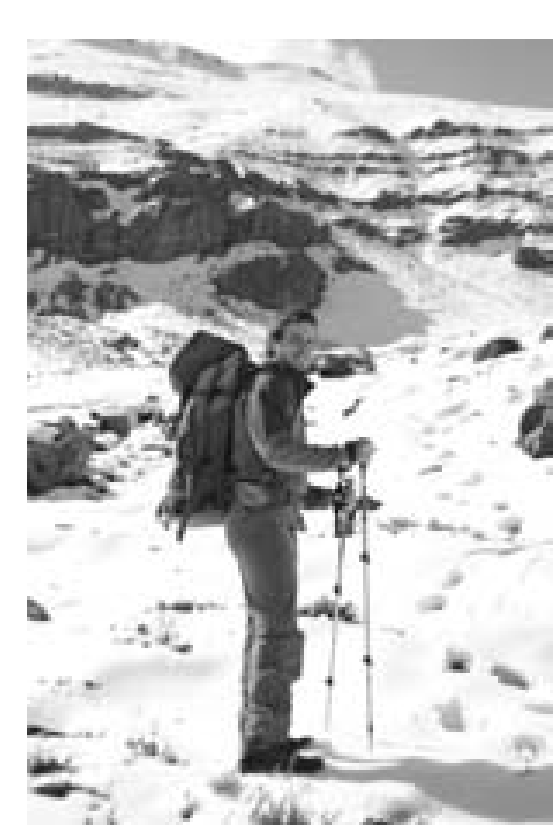
de montaña, por lo que el GOPE de Carabineros y el SAR de la Armada cumplen estas funciones, pero no está dentro de sus prioridades. Es por esto que la mejor garantía para un montañista en los Andes es que sus compañeros estén preparados para realizar un rescate.

Mi proyecto busca dar solución al problema de atender, inmovilizar y transportar a un accidentado o enfermo en entornos remotos no-urbanos con elementos disponibles del equipo utilizado por el montañista en los Andes Centrales de Chile.

Trabajar con los elementos que comúnmente son llevados a la montaña es sumamente importante ya que los usuarios no están dispuestos a llevar equipos extras, puesto que aumentarán el peso que cargan en sus mochilas. El análisis se centra en la mochila de montaña, que es el elemento que se encuentra presente en los distintos momentos de un ascenso o en una expedición.
La solución que se propone es un sistema de autorrescate el cual está compuesto por tres elementos:

I. Una camilla

2. El botiquín

3. Inmovilizaciones

Los cuales se integraron al equipo de montaña comúnmente usado, creando una mochila que se transforma en una camilla de rescate, la cual tiene integrado un botiquín. También se diseñó una colchoneta que se transforma en inmovilizaciones para los accidentes más comunes.

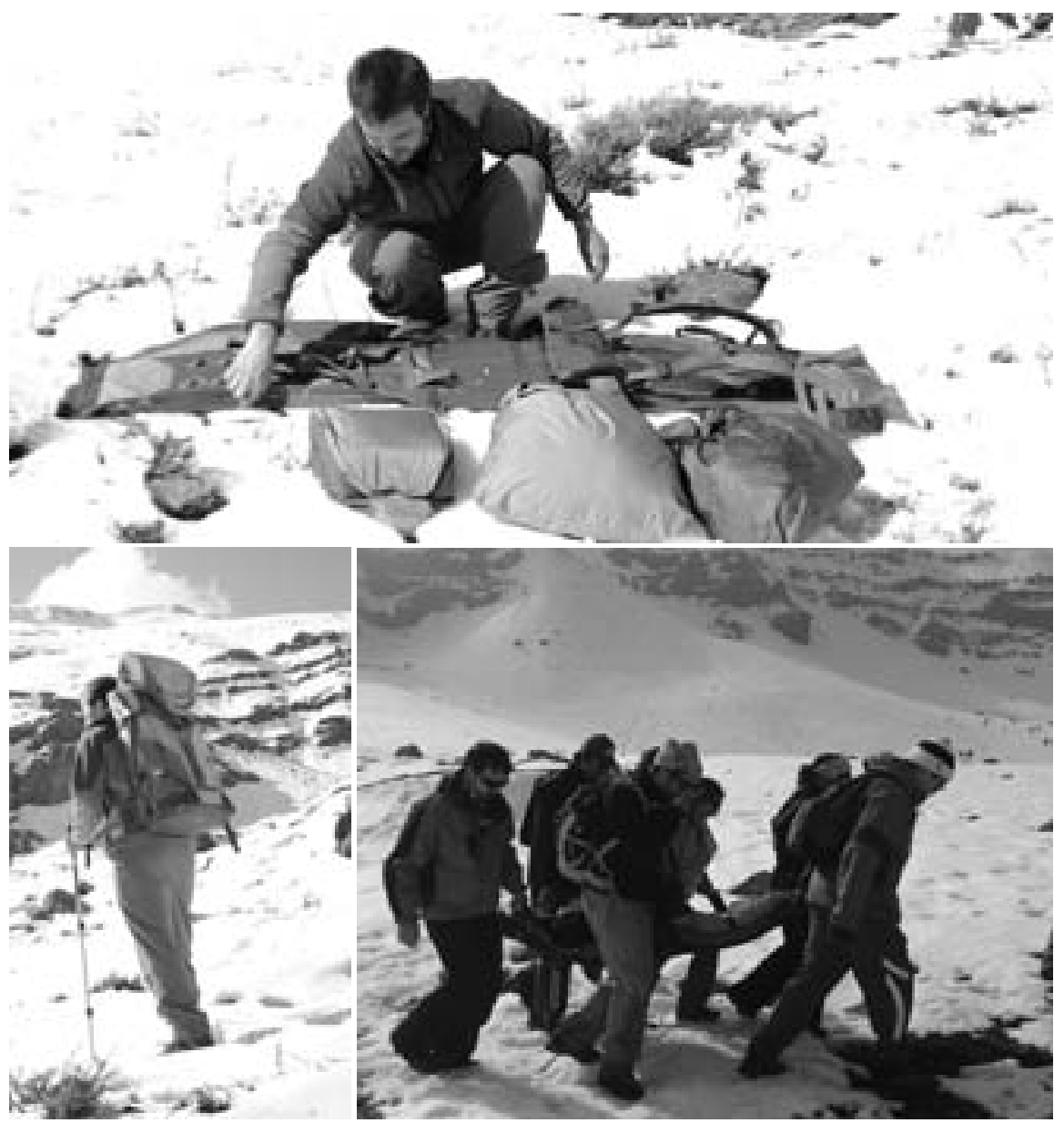

